\title{
Sustainable Livelihood Approach Addressing Community's Economic Distress Facing the Covid 19 Outbreak: A Methodological Concept
}

\author{
Achmad Room Fitrianto ${ }^{1, *}$
}

${ }^{1}$ Lembaga Pengembangan Kewirausahaan dan Bisnis Islam (The centre for Islamic Entrepreneurship and Business) The State Islamic University of Sunan Ampel Surabaya

*Corresponding author.Email: ar.fitrianto@uinsby.ac.id

\begin{abstract}
Man-made or natural disaster, both create community economic distress; it makes the degree of accessing regular source of community income more difficult to be reached. Within a certain time when there are no improvements in mitigation and anticipation, it will bring poverty in the community.

In December 2019 has been found severe acute respiration syndrome coronavirus 2 that identified in Wuhan China and spread worldwide. In Indonesia there was 700,097 cases of infections nationwide and bring to death toll to 20,847. Inability to completely control or prevent disasters, trigger social change. The basis of social change is the changes process of human thought. These changes can refer to the dynamics of cultural values or social evolution. Social change, the process of certain social or cultural development under strong stimulation. Therefore, historical background data are essential in understanding people behaviour. Conceptually, this proposal employ sustainable livelihood in capturing the community's economic distress that is constructed by the environment changes especially the danger of corona virus spread.

In portraying community desire and intention in responding the environment changes and other factors that potentially create vulnerable condition cannot be separated from the community assets. Those assets that owned by the community are physical assets, human asset, social asset and financial support. Owing to the aim of this research is to strengthen the process of community adaptation behaviour toward the disaster and other threats; it seems the use of sustainable livelihood approach is methodologically correct. However the limitations of utilising this method require a long term and cyclical process of research. The strength of this method will provide a comprehensive approach in identifying factors that determine the community distress and able to identify community resilience based on the community consensuses through the assets and potencies mapping.
\end{abstract}

Keywords: Disaster, economic distress, Corona Virus, sustainability livelihood.

\section{INTRODUCTION}

Covid-19 is a new virus that was first discovered in Wuhan, Hubei Province, China. According to the World Health Organization (1), (2), Covid-19 is an infectious disease caused by coronavirus, which is a group of diseases that can cause animal or human diseases. Previously, the virus only occurred in Wuhan and China (3), because the spread of the virus to other countries/regions has increased and many people have been infected $(2,4)$. Most people who fall ill with COVID-19 will have mild to moderate symptoms and can recover without special treatment.
Covid19 can rapidly develop into acute respiratory distress syndrome (ARDS) in elderly patients over 60 years of age with a high mortality rate, especially in individual comorbidities such as diabetes, cancer, lung disease and hypertension $(2,5)$. Covid19 is the cause of a potentially fatal disease that has attracted global public health attention(2)

The virus that causes COVID- 19 is spread mainly through droplets produced when an infected person coughs, sneezes or exhales $(5,6)$. These water droplets are too heavy to hang in the air and quickly fall to the floor or ground. People who are close to 
someone infected with COVID-19 can get infected by accidentally inhaling the virus or touching a contaminated surface, and then touching the eyes, nose or mouth $(2,6)$.

As of January 30, 2020, China has confirmed 7734 cases (2). Globally the virus spread in Taiwan, Thailand, Vietnam, Malaysia, Nepal, Sri Lanka, Cambodia, Japan, Singapore, South Korea, United
Arab Emirates, United States, Philippines, India, Australia, Canada , Finland, France and Germany (2)

The first case in Indonesia recorded on March 2, 2020 , and at recent days the total numbers of COVID 19 infections nationwide are 743,198 . This virus taking the total number of fatalities to 7,616, the highest death toll in Southeast Asia

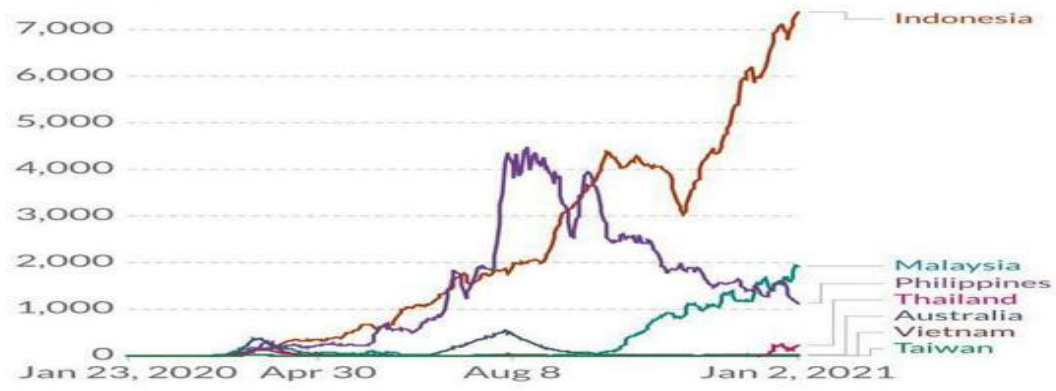

Chart 1 COVID 19 CASES in six countries

Sources: John Hopkins University CSSE COVID 19 Data- Last updated 3 January 2021, 23:06 London Time

Jakarta recorded 2022 new confirmed cases, bringing the total to 183,735 . At the same time, 1,024 new cases were reported in West Java, 939 in Central Java, 935 in East Java, 479 in South Sulawesi, and 364 in East Kalimantan. Since the first casualty was confirmed on March 11, 2020, Indonesia has recorded 19,514 coronavirus deaths.

This virus not only attacks human health but also attacks all areas of life, one of which is in the economic field. The Covid-19 pandemic has imposed restrictions on community activities, which will affect business activities, which in turn will have an impact on the Indonesian economy. That is, economic growth has reduced the number of unemployed people and reduced foreign investment.

The Central Bureau of Statistics (BPS) reported in August this year that Indonesia's economic growth in the second quarter of 2020 was negative $5.32 \%$. Previously, BPS reported in the first quarter of 2020 that Indonesia's economic growth only increased by $2.97 \%$, which was far lower than the $5.02 \%$ in the same period in 2019. This weak economic performance has also had an impact on Indonesia's labor force.

Obstructing economic activity cause business has to more efficient to reduce losses. Reducing cost of production is one of the options through sending workers home or even fired. According to data from the Ministry of Manpower as of April 7, 2020, 39,977 companies in the formal sector have reduced their employee due to the Covid-19 pandemic. The total number of workers affected by this is $1,010,579$. Specifically, 873,090 workers from 17,224 companies were laid off, while 137,489 workers from 22,753 companies were fired. At the same time, the number of companies and workers affected by the informal sector is 34,453 companies and 189,452 workers.

From the perspective of sector distribution, trade is the sector that absorbs the most labor. Estimated results indicate that the number of employed persons in this sector has decreased by approximately 677,100-953,200. However, from a proportional point of view, the construction industry is the sector that has reduced employment the most, accounting for $3.2 \%-4.5 \%$ of the total number of workers in this sector by February 2020. However, it is estimated that some sectors still absorb labor, such as education services, information and communications, health services and social activities, and financial services and insurance. This may be because the sector's gross domestic product (GDP) increased in the first quarter of 2020 compared to the same period in 2019.

As can be seen from the background description above, the widespread of Covid 19 has caused economic difficulties. Human existence tends to relate danger, helplessness, and vulnerability (7). Therefore, in order to identify factors that determine community economic vulnerability and identifying the community resilience a research methodology that able to record all aspect in the community are 
needed. The purpose of this article is to simulate the use of sustainable livelihoods to identify the economic distress of the community caused by the spread of COVID 19.

\section{INTERVENTION METHOD AND APPROACHES}

Conceptually, the proposal depicts the development of a socio-economic and ecological approach to the development of an understanding of a community's behaviour, especially those with small income in seeking solutions to economic difficulties. Portraying the desire and intention of communities to respond to environmental changes, such as the COVID 19 outbreak, requires sustainable livelihood research. The research aimed to map the community assets owned; tangible assets, human assets, social assets and financial support.

Investigating the community's response to the economic distress caused by the COVID 19 pandemic classified as behavioural research. The concerns of community members as individuals or groups depend on the knowledge structure developed

(8), the use of sustainable livelihood approach is precisely correct in portraying community reaction in seeking a solution of economic distress. The framework is classified as participatory rural assessment, which mainly uses multiple methods in data collection, including structured questions performed in questionnaires, semi-structured interviews, and auxiliary data analysis. To enrich the data analysis, the study combines qualitative and quantitative data. In order to capture local perspectives, the researcher intends to keep in touch with the community to familiarize the researcher with the problems facing the community. By directly participating in community activities, researchers can capture trends and behaviours with minimal attention. The key problem to be solved in action research is to develop and discuss possible solutions to the problems faced, and to seek actions that may reduce the negative impact of the problems being solved.
The three reasons for using participatory action research are that, first, action research can easily record the occurrence of social change, which is because social actors participate in the research as insiders (9-11) Some traditional barriers can be broken, and evaluated and modified according to the latest trends. Secondly, by carrying out action/participatory research and actively involving social participants in the research, it can not only collect data for researchers, but also can be used as part of the community education process to understand the social symptoms of the research object. (9-11). Last but not least, action-participatory research provides more opportunities for emerging theories, rather than abandoning previously proposed theories (11). Therefore, participatory action research can convey the life story of the community.

The sustainable livelihood approach is a holistic approach that was originally designed to help understand the many causes of poverty and find sustainable livelihood solutions for those most in need (12-15). The five stages of SLA are: identifying the vulnerabilities in a given community; mapping the livelihood assets owned by the community; observing the structure and process of transformation; determining livelihood strategies and formulating livelihood results (12-15).

Another consideration behind participatory action research is self-criticism and higher-level thinking. This is because researchers must capture the society wrapped in community structure functions, conflicts experienced by the community, and symbolic interactions between community counterparts Factual paradigm. Therefore, participating in action research tends to use various stages in the research cycle to locate problems and predict the priorities that need to be carried out (16). Since the main purpose of this research is to provide policy recommendations to support the creativity and innovation of the community in the face of disasters, a circular process is required. The repetition depends on the previous information provided and aims to record the deepest mainstream in society.

The following chart describes those aspects of the cyclic process involved. 


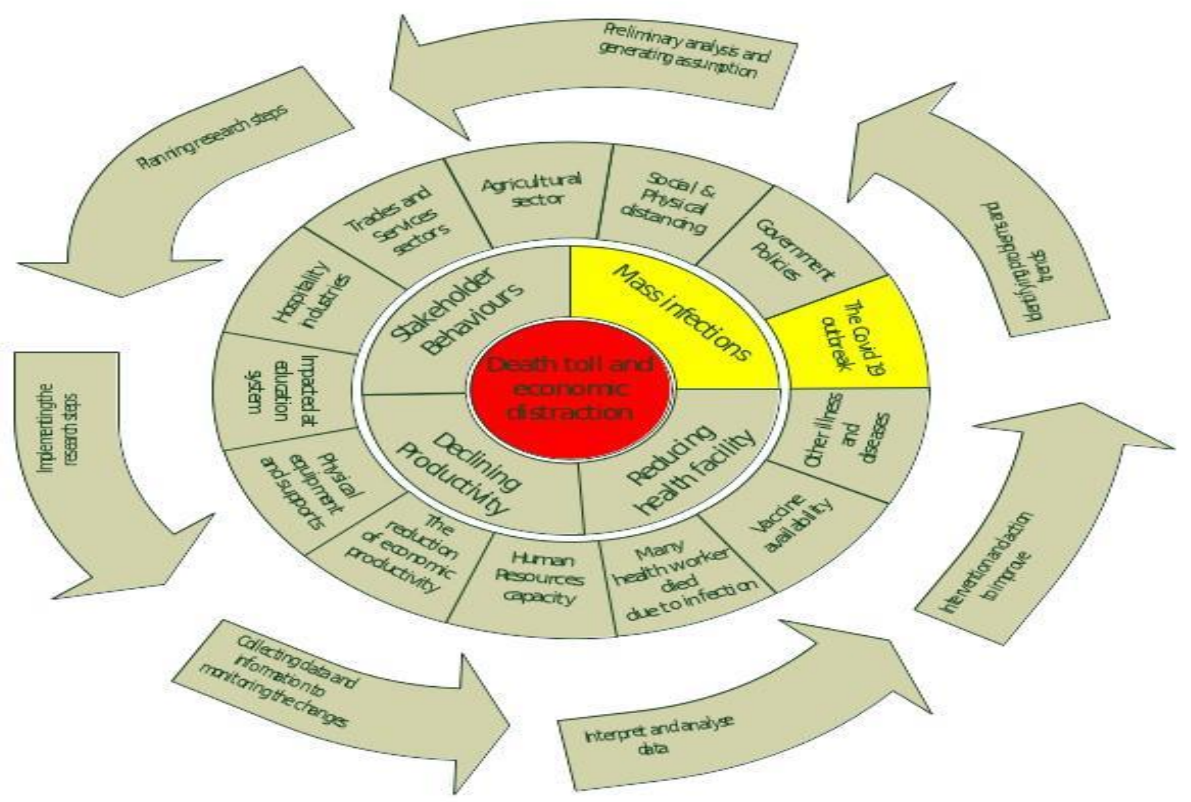

Chart 2 Circular processes in gathering data and information

As can be seen from the above flow chart, the cycle of participatory research starts by defining the problems faced and continues by observing the community's activities in solving the problems. The next round collects data required by various shareholders (such as traders, informal workers, and workers employed by the hotel industry). It is necessary to explain and analyze the community strategy portfolio that maximizes the use of key resources and elements to deal with potential harm. After explaining and analyzing the behavioural groups of community members, the next stage is needed to understand the perspectives of associations, economics actors, and government agencies to balance the information collected from these three groups that are most vulnerable due to social distancing due to COVID 19. The final stage of the cycle is the analysis and weighing of the results, in order to weigh each corresponding response to the threat. In order to complete the study, it is necessary to conduct a strategic simulation that considers the entire obstacle that may occur. However, when developing strategy simulations, you need to consider further identifying potential problems that hinder the simulation. The identified issues will be used for further research or other policy measures.

\section{LESSONS}

The sustainable livelihood approach is sufficient to investigate the economic difficulties of community members for two reasons. First, SLA is classified as one of the research activities leading to policy analysis. Second, SLA can also be used to identify and observe human behaviour, that is, human response to fragile factors that affect their lives. In this terminology, the research aims to investigate the efforts of community members to solve the economic difficulties caused by the virus outbreak. Therefore, the SLA framework can be used for communities' distress analysis.

The chart below shows the work of the sustainable livelihood approach 


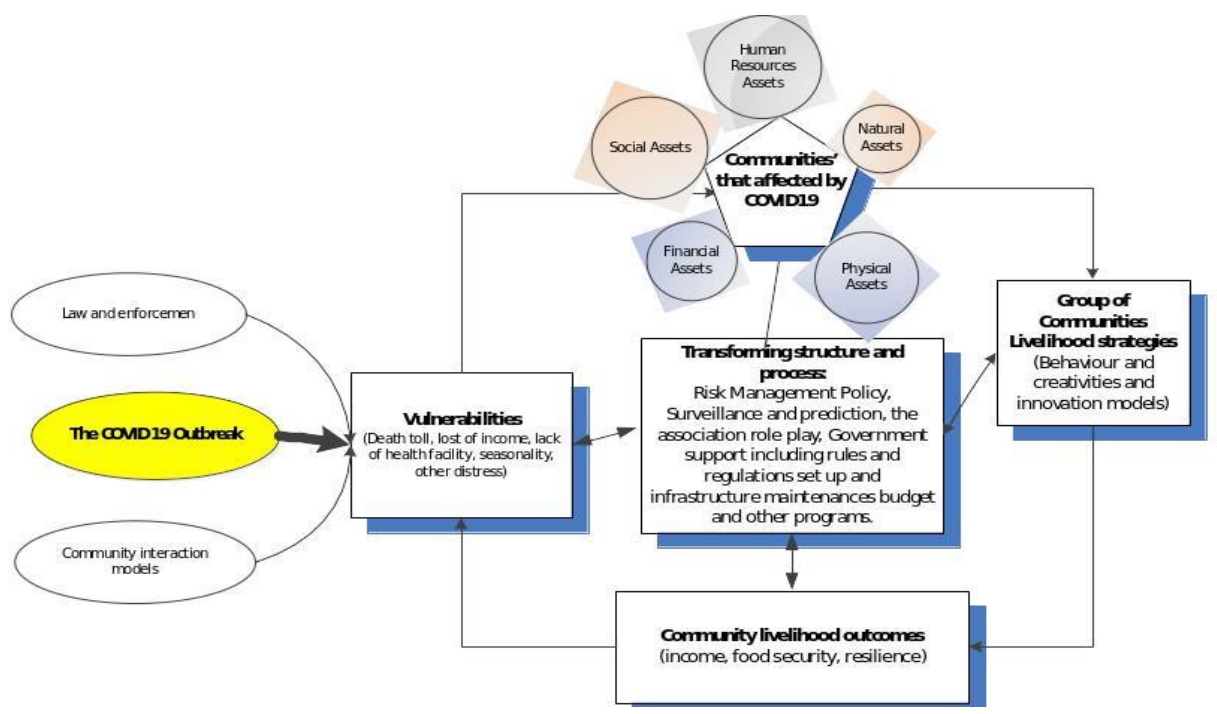

Chart 3 SLA Process in investigating Community economic distress

By determining community assets and the factors that lead to community fragility, the social structure transformation of the community can be promoted. After drawing the fragile map, the people's livelihood strategy and the people's livelihood results can be used as the government's basic consideration when formulating policies. The use of constructivist interpretation frameworks such as SLA helps to develop understanding through the joint construction of knowledge (17).

Recently, people have been trying to extend the SLA framework beyond poor households to include people with different economic and social backgrounds (12, 14). However, Scoones (14) and Kelman and Mather (18) have already drawn attention to the fact that SLA practitioners have been resisting asking local residents about broader structural constraints on their control or limited influence. To some extent, this is because SLA's strength lies in its focus on improving local vision and building the local ability to obtain positive results from below. However, even at this level, if SLA practitioners rely on mechanical processes and managerial methods, they may produce livelihood strategy recommendations, ignoring the importance of historical and cultural attachment to specific practices and work arrangements (18). This is important for the COVID 19 outbreak, because many people face difficult choices: either implement social distancing policies through appropriate support structures and viable livelihood prospects, or allow people to live normally to sustain their lives. People's livelihoods are satisfied, but the risk of injury or death due to infection, coexisting diseases and economic pressure has increased, and people's livelihood capacity has declined. In recent health crises like this, the decision of the community depends on the preparedness of the health system. This preparation must be based on the understanding of limited local capabilities. This is affected by the understanding of the order of the virus, and in some cases it is usually based on politics. Motivation, such as providing halal vaccines or quarantine policies that affect the well-being of the community (19).

In addition, Scoones (14) considers the potential of establishing a more responsive SLA through the perspective of "knowledge, politics, scale and motivation". He believes that in order to accurately understand social issues in society, priority will be given to predictions in trans-disciplinary and cross-sectoral in microeconomic analysis. These predictions can guide and focus the understanding of events in the field between institutions. Reducing discourses among institutions, social movements, government and policy practitioners (14). Since SLA analysis is developed based on the accuracy of the collected social information and can reduce the discourse of the organization, SLA analysis pays less attention to power and political dynamics. Therefore, two issues identified firstly the undetailed analysis of macro and micro contexts and the agency and structure dynamic (14). According to Baumann (20) observation of the power relationship that cannot be included in the neat points of the asset pentagon but it is particularly relevant to the situation of the community's member that face economic difficulties. Economic difficulties caused by the COVID 19 outbreak world-wide. Local responses to the shock of COVID 19 outbreak can only be understood in the context of global market forces and supply chains, and potential long-term environmental and social risks to other local actors from peasant economic actors dominant at the time the social restriction commenced. 
Scoones (14) recognizes that SLA achieved great success as a method of identifying local complexity. Furthermore, many practitioners' emphasis on rigour and rationality of SLA leads to a narrow definition of output which constitutes to an appropriate livelihood and how to achieve better livelihood. This echoes the call of Kapadia (21), which requires people to think more carefully about the relationship between disaster and development, especially on how to measure development $(22,23)$.

From another perspective, the use of public participation often delays the implementation of policies. These delays caused by the community are the main source of policy considerations. Communities composed of multiple ethnic groups, ideologies, and interests often have different views on the issues they face. Therefore, in addition to decision-makers who have certain methods and techniques to summarize the needs and wishes of the community, it will take time and effort to involve the community in the public policy process. In order to limit and concentrate the policy issues that should be set, a framework based on preliminary assumptions must be prepared.

There are some examples that show that participatory research has taken shape at certain stages of advocacy policy. The first is the participatory poverty assessment conducted in Ghana in the mid-1990s, which used a variety of poverty reduction methods, and the second is the Indonesian Rapid Decentralization (IRDA) by the Asia Foundation in response to the challenges of Indonesia's decentralization reforms in the early 2000s.

\section{CONCLUSION}

The sustainable livelihood approach in picturing the community in pandemic not only to reducing the negative of social distancing apply, but also to observe the community behaviour in facing the economic distress that caused by the slowdown of economic activities due to the social distancing. Portraying the community innovation and efforts in seeking solution of their economic distress could be categorised as a part of risk management that has been taken in anticipating the social and environment change. In other consideration could be saying that the use of participatory action research could be used for doing risk management mapping. Disasters, whether natural or man-made including the COVID 19 outbreak, generally have a greater negative impact on the poor Therefore portraying the community behaviour and efforts that aimed for reducing their economic distress and their potential vulnerability using sustainable livelihood are precisely appropriate

\section{REFERENCES}

1. World Health Organization. Pneumonia of unknown cause-China. Geneva: World Health Organization; 2020. 2020.

2. Rothan HA, Byrareddy SN. The epidemiology and pathogenesis of coronavirus disease (COVID-19) outbreak. Journal of autoimmunity. 2020:102433.

3. Zhu N, Zhang D, Wang W, Li X, Yang B, Song $\mathrm{J}$, et al. A novel coronavirus from patients with pneumonia in China, 2019. New England Journal of Medicine. 2020.

4. Kuchler T, Russel D, Stroebel J. The geographic spread of COVID-19 correlates with structure of social networks as measured by Facebook. National Bureau of Economic Research; 2020. Report No.: 0898-2937.

5. Hadi MI, Widiyanti M, Kumalasari MLF, Alamudi MY, Suprayogi D. Management of SarsCov-2 Medical Waste Against a Covid19 Pandemic in Indonesia: A Literature Review. JURNAL KESEHATAN LINGKUNGAN. 2020;12(4):24453.

6. Komarova NL, Schang LM, Wodarz D. Patterns of the COVID-19 pandemic spread around the world: exponential versus power laws. Journal of the Royal Society Interface. 2020;17(170):20200518.

7. Kasperson RE, Pijawka KD. Societal response to hazards and major hazard events: Comparing natural and technological hazards. Public Administration Review. 1985;45:7-18.

8. Nelson MW, Libby R, Bonner SE. Knowledge Structure and the Estimation of Conditional Probabilities in Audit Planning. Accounting Review. 1995;70(1):27-47.

9. Carr W, Kemmis S. Becoming critical: education, knowledge, and action research. Kemmis S, editor. London Philadelphia: London Philadelphia: Falmer Press; 1986.

10. Pedretti E, Hodson D. From rhetoric to action: Implementing sts education through action research. Journal of Research in Science Teaching. 1995;32(5):463-85.

11. Koshy V. Action Research for Improving Practice: A Practical Guide. London: London: Sage Publiations Ltd.; 2005.

12. Chambers R, Conway G. Sustainable rural livelihoods: practical concepts for the 21st century. IDS Discussion Paper 296 [Internet]. 1992. Available from: http://opendocs.ids.ac.uk/ opendocs/bitstream/handle/123456789/775/ Dp296.pdf? sequence $=1$. 
13. DFID. DFID sustainable livelihoods guidance sheets. In: Development DfI, editor.: Department for International Development; 1999.

14. Scoones I. Livelihoods perspectives and rural development. Journal of Peasant Studies. 2009;36(1):171-96.

15. Ludi E, Slater R. Using the Sustainable Livelihoods Framework to understand and tackle poverty. In: Cooperation SAfDa, editor. 2008.

16. McIntyre A. Participatory action research / Alice McIntyre. Los Angeles: Los Angeles: Sage Publications; 2008.

17. Guba EG, Lincoln YS. Paradigmatic controversies, contradictions, and emerging confluences. In: Denzin NK, Lincoln YS, editors. the SAGE handbook of qualitative research. Thousand Oaks: Thousand Oaks: Sage Publications; 2005.

18. Kelman I, Mather TA. Living with volcanoes: The sustainable livelihoods approach for volcano-related opportunities. Journal of Volcanology and Geothermal Research. 2008;172(34):189-98.

19. Hoath A. Giving voice to Porong mud volcano victims: Environmental advocacy and issues of representation in Indonesia. the 8th Conference on Environmental Justice and Global Citizenship: Environmental Ethics, Sustainability and Education; Mansfield College, Oxford2009.

20. Baumann P. Sustainable livelihoods and political capital: Arguments and evidence from decentralisation and natural resource management in India. Working Paper 136 [Internet]. 2000. Available from:

http://www.mtnforum.org/sites/default/files/pub lication/files/3367.pdf.

21. Kapadia KH. Developments after a disaster: The tsunami, poverty, conflict and reconstruction in Sri Lanka [Ph.D.]. Ann Arbor: University of California, Berkeley; 2008.

22. Timms BF. The (Mis)Use of Disaster as Opportunity: Coerced Relocation from Celaque National Park, Honduras. Antipode.

2011;43(4):1357-79.

23. Klein $\mathrm{N}$. The shock doctrine: the rise of disaster capitalism / Naomi Klein. London: London: Allen Lane; 2007. 